\title{
Opportunistic infections in immunosuppressed patients with juvenile idiopathic arthritis: analysis by the Pharmachild Safety Adjudication Committee
}

Gabriella Giancane ${ }^{1 \dagger}$, Joost F. Swart ${ }^{2 \dagger}$, Elio Castagnola ${ }^{3}$, Andreas H. Groll ${ }^{4}$, Gerd Horneff ${ }^{5,6}$, Hans-lko Huppertz ${ }^{7}$, Daniel J. Lovell ${ }^{8}$, Tom Wolfs ${ }^{2}$, Troels Herlin ${ }^{9}$, Pavla Dolezalova ${ }^{10}$, Helga Sanner ${ }^{11,12}$, Gordana Susic ${ }^{13}$,

Flavio Sztajnbok ${ }^{14}$, Despoina Maritsi ${ }^{15}$, Tamas Constantin ${ }^{16}$, Veronika Vargova ${ }^{17}$, Sujata Sawhney ${ }^{18}$, Marite Rygg ${ }^{19,20}$, Sheila K. Oliveira ${ }^{21}$, Marco Cattalini ${ }^{22}$, Francesca Bovis ${ }^{1}$, Francesca Bagnasco ${ }^{1}$, Angela Pistorio ${ }^{23}$, Alberto Martini ${ }^{24}$, Nico Wulffraat ${ }^{2+}$, Nicolino Ruperto ${ }^{1 *}$ and for the Paediatric Rheumatology International Trials Organisation (PRINTO)

\footnotetext{
Abstract

Background: To derive a list of opportunistic infections (OI) through the analysis of the juvenile idiopathic arthritis (JIA) patients in the Pharmachild registry by an independent Safety Adjudication Committee (SAC).

Methods: The SAC (3 pediatric rheumatologists and 2 pediatric infectious disease specialists) elaborated and approved by consensus a provisional list of $\mathrm{OI}$ for use in JIA. Through a 5 step-procedure, all the severe and serious infections, classified as per MedDRA dictionary and retrieved in the Pharmachild registry, were evaluated by the SAC by answering six questions and adjudicated with the agreement of 3/5 specialists. A final evidence-based list of OI resulted by matching the adjudicated infections with the provisional list of OI.

Results: A total of 772 infectious events in 572 eligible patients, of which 335 serious/severe/very severe non-Ol and $437 \mathrm{Ol}$ (any intensity/severity), according to the provisional list, were retrieved. Six hundred eighty-two of 772 (88.3\%) were adjudicated as infections, of them 603/682 (88.4\%) as common and 119/682 (17.4\%) as Ol by the SAC. Matching these 119 opportunistic events with the provisional list, 106 were confirmed by the SAC as OI, and among them infections by herpes viruses were the most frequent (68\%), followed by tuberculosis (27.4\%). The remaining events were divided in the groups of non-Ol and possible/patient and/or pathogen-related OI.

(Continued on next page)
}

\footnotetext{
* Correspondence: nicolaruperto@gaslini.org

${ }^{\dagger}$ Gabriella Giancane, Joost F. Swart and Nico Wulffraat contributed equally to this work.

'IRCCS Istituto Giannina Gaslini, Clinica Pediatrica e Reumatologia, PRINTO, Genoa, Italy

Full list of author information is available at the end of the article
}

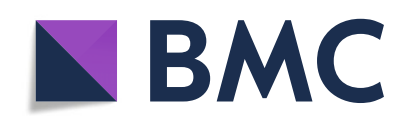

( ) The Author(s). 2020 Open Access This article is licensed under a Creative Commons Attribution 4.0 International License, which permits use, sharing, adaptation, distribution and reproduction in any medium or format, as long as you give appropriate credit to the original author(s) and the source, provide a link to the Creative Commons licence, and indicate if changes were made. The images or other third party material in this article are included in the article's Creative Commons licence, unless indicated otherwise in a credit line to the material. If material is not included in the article's Creative Commons licence and your intended use is not permitted by statutory regulation or exceeds the permitted use, you will need to obtain permission directly from the copyright holder. To view a copy of this licence, visit http://creativecommons.org/licenses/by/4.0/. The Creative Commons Public Domain Dedication waiver (http://creativecommons.org/publicdomain/zero/1.0/) applies to the data made available in this article, unless otherwise stated in a credit line to the data. 
(Continued from previous page)

Conclusions: We found a significant number of $\mathrm{OI}$ in JIA patients on immunosuppressive therapy. The proposed list of Ol, created by consensus and validated in the Pharmachild cohort, could facilitate comparison among future pharmacovigilance studies.

Trial registration: Clinicaltrials.gov NCT 01399281; ENCePP seal: awarded on 25 November 2011.

Keywords: Infections, Opportunistic, Juvenile idiopathic arthritis, Immunosuppressive therapy, Biologics

\section{Background}

With the advent of biologic disease-modifying antirheumatic drugs (DMARDs), in a chronic condition like juvenile idiopathic arthritis (JIA), regulatory authorities such as the Food and Drug Administration (FDA) and the European Medicines Agency (EMA) have demanded from pharmaceutical companies and clinical researchers to evaluate the long-term safety of drugs used in children enrolled in phase II-III clinical trials [1-16]. Due to the limited number of patients enrolled in these trials [17], clinical researchers have devoted their work to the implementation of national and international registries [18-28] or to the analysis of insurance claim data [29-31].

During their development, all children experience a natural rate of infections compared to adults. Treatments in JIA with synthetic and biologic DMARDs are expected to increase the frequency of common infections and the risk of serious and opportunistic infections (OI) [23, 30-34], including especially tuberculosis in some geographic areas [35-37]. In order to tackle the long-term safety and efficacy evaluations, the Paediatric Rheumatology INternational Trials Organization (PRINTO) started in 2011 the "Pharmacovigilance in Juvenile Idiopathic Arthritis patients" (Pharmachild), an observational international registry supported by a European Union grant [38, 39].

Recent literature seems to confirm the high incidence of infections among JIA patients treated with immunosuppressants [21], but conclusive data are not available, yet. In particular, little evidence exists about the role of JIA or its immunosuppressive therapy in acquiring OI.

Several studies in the literature have the objective to define and classify OI, for example in HIV or in cancer patients [40-43]. In rheumatology, Winthrop and colleagues [32] were the first to convene a consensus meeting in 2015 to review the published literature on OI in patients with immune-mediated diseases treated with biologic DMARDs, in order to provide consensus recommendations for their evaluation in the context of clinical trials and observational studies.

Primary objectives of the present study were to derive a consensus-based list of opportunistic pathogens for use in children with JIA and confirm its role in identifying OI through the evaluation of the infectious events reported in Pharmachild registry by an independent Safety Adjudication Committee (SAC).

\section{Methods}

\section{Pharmachild}

The Pharmachild registry (project number 260353) involves 86 participating PRINTO (www.printo.it) centers in 32 countries [38] and the Paediatric Rheumatology European Society (PRES at www.pres.eu), with the aim to (1) monitor children with JIA for disease activity and comorbidity; (2) compare the long-term incidence rates of moderate, severe, and very severe adverse events (AE) and serious AE (SAE); and (3) assess the long-term efficacy of biologic and synthetic DMARDs in JIA. The Pharmachild registry contains both a retrospective and a prospective cohort. In brief, the retrospective cohort includes data from patients under treatment or previously treated with DMARDs obtained by one-time clinical chart review for safety events and complete drug exposure since disease onset to last available follow-up; the prospective cohort includes all cases newly treated with DMARDs since enrollment in the registry and cases still under treatment with any drug. In case of repeated events (e.g., infection with multiple reporting in the registry for the follow-up evaluation), only the initial event was considered. Full details of the registry methodology are available elsewhere [39].

\section{Study design}

The study was divided into 5 main steps (additional figure 1).

\section{Step 1: Provisional listing of opportunistic pathogens/ infection presentations}

The study Steering Committee (SC) included two $\mathrm{PhD}$ medical doctors (GG and JS), two certified Medical Dictionary for Regulatory Activities (MedDRA) coders (CP, $\mathrm{LV}), 3$ biostatisticians (AP, FB, FB), and two Senior researchers (NW, NR).

The SAC was organized as an independent group of 5 physicians: 2 pediatric infectious disease specialists (EC and $\mathrm{AG}$ ) and 3 pediatric rheumatologists $(\mathrm{GH}, \mathrm{HIH}$, $\mathrm{DL})$, who have experience and expertise in the diagnosis and treatment of children with infectious or rheumatic diseases.

The SC starting point was the prior work by Winthrop et al. [32], an international consensus committee (infectious disease, public health, and pulmonary physicians and rheumatologists) that recommended a list of definite 
and probable OI after systematic review of literature on immune-mediated disorders (including JIA), and a consensus process. This list was discussed, modified, and approved by consensus by the SAC, through three subsequent Delphi web rounds, with the final result of a list of opportunistic pathogens/presentations for use in immunosuppressed children with JIA. In the first round, SAC members worked independently from each other, while during the second round, they could also revise their responses based on the review of comments from the other members. Final consensus was reached through a dedicated teleconference (moderator NR).

The SC then integrated the review of the literature with more recent evidence on OI in JIA [31, 44, 45] and prepared a provisional list of OI pathogens, then matched them with the MedDRA Preferred Terms (PT) in order to retrieve correctly the cases from the Pharmachild database. This provisional list was not shared with the SAC members as it was used only for data retrieval (see next step).

\section{Step 2: Retrieval of infections in Pharmachild}

For the Pharmachild study, the treating physicians reported online in the registry database all AEs from the disease onset to the last available follow-up visit. All terms contained in the MedDRA System Organ Class (SOC) "Infections and infestations" were considered in Pharmachild as Events of Special Interest (ESI) and classified in two different ESI sub-groups, named "tuberculosis" and "targeted infections (Epstein-Barr virus, cytomegalovirus, papilloma virus, herpes zoster primary and reactivation, and opportunistic infections)."

According to the Pharmachild protocol, all events (AEs and ESIs) of at least moderate intensity and all SAEs were collected. AEs and ESIs were coded initially by the treating physicians during data entry using the MedDRA dictionary, then recoded, if needed, by PRINTO-certified MedDRA coders and revised by the PRINTO medical monitor (JS), based on the most current version of MedDRA.

All infectious events (both initial and follow-up) in the MedDRA system organ class (SOC) (additional figure 2) "Infection and infestations" in Pharmachild as of January 2017 were retrieved (Fig. 1).

\section{Step 3: Adjudication of infections by the SAC}

A standard operating procedure (SOP) described the work to be done by the SAC. In brief, the SAC adjudication process included all the opportunistic events in the provisional list of OI derived by step 1 (any grade of severity) plus the non-OI infections of at least severe intensity and all serious infections from both retrospective and prospective charts.
The list of the events to be adjudicated by the SAC was provided in a dedicated external area of the PRINTO/Pharmachild website, with access through secure personal username and password.

The SAC members who reviewed all eligible cases (presented in numerical order by patient's code) did not participate in the data collection in Pharmachild.

The complete patients' data were available for the SAC members: (1) demographic characteristics of the patient (with personal data encrypted), (2) ILAR category of JIA, (3) laboratory and clinical information, (4) complete drug therapy with whole drug exposure for synthetic and biologic DMARDs since disease onset to the last available observation, (5) concurrent medications at the time of the infectious event, and (6) full AE report plus ESI-specific form for infections. In addition, JIA disease activity and a damage measure were available for prospective visits. The SAC members had the possibility to access the complete clinical information in a read-only mode, with no possibility to modify the original data. A numeric code, without any patient or center identifier and no a priori categorization of $\mathrm{AE}$ as $\mathrm{OI}$, was provided to decrease potential bias during the adjudication exercise.

The SAC mandate was to evaluate each infectious case, based on the whole patient's history available in Pharmachild, by answering 5 questions: (1) Based on the information provided, do you confirm that this patient had an infection?; (2) Is this infection common?; (3) Is this an opportunistic infection?; (4) Was the treatment appropriate for the infection?; (5) Could the event be possibly related to any of the $\operatorname{drug}(\mathrm{s})$ taken at the time of the event? The study SC was available to provide any additional information related to the event and required by the SAC at any time.

The consensus among the SAC members was defined as an agreement of at least 3 out of $5(60 \%)$ members, on the first 3 out of 5 adjudication questions ("Is this an infection?," "Is it common?," "Is it opportunistic?"). Initially, the SAC members worked independently from each other, while in the next phase, for all cases without consensus, each member could access the evaluations of the other SAC members.

\section{Step 4: Analysis of the Pharmachild registry}

Step 4 was designed to evaluate, in an evidence-based fashion, the frequency of those events in the Pharmachild registry classified as infections by consensus among the SAC and to assign a final MedDRA code (High Level Term (HLT)/PT) to the event. In case of discrepancies in the categorization, after PRINTO and medical monitor (JS) check, a third independent examiner (GG) reevaluated the individual case and assigned the final MedDRA code (HLT/PT). 


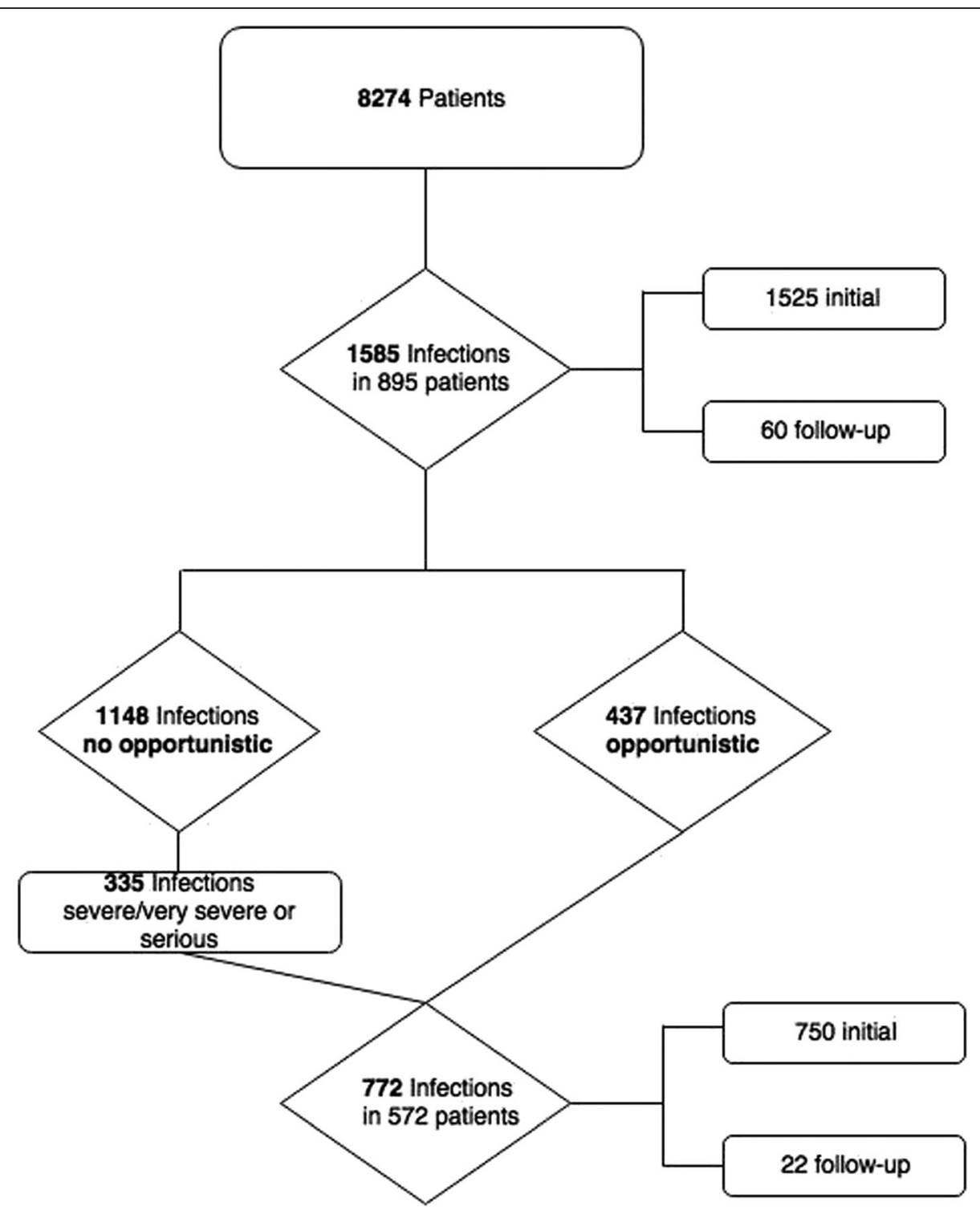

Fig. 1 Flowchart of the Pharmachild population with infectious events

Step 5: Final evidence-based listing of opportunistic pathogens/infection presentations

In this step, all the infectious events adjudicated by the majority of the SAC in Pharmachild were matched by MedDRA PT term with the provisional list of OI (see step 1) and divided in three groups: "confirmed OI," if there was full agreement between the SAC and the provisional list of OI; "confirmed non-OI," for the events adjudicated as non-OI by the SAC and missing in the provisional list; "possible/patient and/or pathogenrelated OI," for the remaining events in Pharmachild that could be possibly considered opportunistic depending on the physician's evaluation of the patient history and by the detection of the specific pathogen causing the disease.

\section{Statistical analysis}

Descriptive statistics were reported in terms of absolute frequencies and percentages for qualitative data. Quantitative data were described in terms of median values and inter-quartile range (IQR) values due to their nonnormal (Gaussian) distribution.

\section{Results}

Step 1: Provisional list of opportunistic pathogens/ presentations

After the three web Delphi rounds, the probable and definite definitions of OI were agreed with one major change by $5 / 5(100 \%)$ of the SAC [32]. In particular, the definition of definite OI was confirmed, while for probable infections, it was integrated with the following: "In 
case of the unusually severe course of infection due to a common pathogen with usually mild disease the pathogen might tentatively be considered opportunistic in a patient with impaired immune function." Two definite categories of pathogens/presentations were modified by the SAC, while twelve were added in the provisional list of probable OI from the literature and matched with the HLT/PT MedDRA dictionary; none of the infections already included in the list by Winthrop et al. [33] was removed.

Table 1 shows the provisional list of pathogens/presentations, with the corresponding HLT terms according to MedDRA dictionary.

\section{Step 2: Retrieval of infections in Pharmachild}

Among the 8274 patients enrolled in the Pharmachild registry as of January 2017, 895 (10.8\%) patients had experienced 1585 infections. A total of 772 events (48.7\%) in 572 patients (Fig. 1 and step 3 of the "Methods" section) were eligible for the evaluation by the SAC, of which 437 were defined as preliminary OI, as per the provisional list of opportunistic pathogens/presentations, and 335 as very severe/severe or serious non-OI events (Fig. 1).

The baseline characteristics of the 572/895 (63.9\%) adjudicated patients are reported in Table 2 in comparison with those who were not adjudicated. Among the 895 patients with infections, about $85 \%$ were from Europe, specifically $29.3 \%$ from Italy and $23.6 \%$ from the Netherlands, while the remaining patients were distributed among Russia (8\%), South America (4\%), Middle East, and India (3\%). The adjudicated group was represented by younger patients, with longer disease duration, higher frequency of systemic JIA, and more frequent use of systemic glucocorticoids.

\section{Step 3: Adjudication of infections by the SAC}

A total of 689/772 (89.2\%) events achieved consensus (3/5 SAC members) on the first 3 adjudication questions, and of these, 682 (99.0\%) were considered as infections by the SAC and included in the analysis (Table 3). The majority of the 682 infections were considered common (88.4\%), with 119 (17.4\%) classified as opportunistic by the SAC after evaluation of the whole patient's history. The consensus on the last 2 questions was more difficult to reach. Regarding the fourth question on the appropriateness of the treatment for the infection, consensus was achieved for 484 (77.1\%) events, while for $140(22.3 \%)$ of the cases, it was impossible to determine the suitability of the anti-infective treatment.

Similarly, for the fifth question about the possible relationship between the infection and the related treatment(s) for JIA, the lack of consensus increased up to 279 (41\%). For $307 / 403$ (76.2\%) cases for which there was consensus, the SAC considered the drug(s) possibly related to the event. When we considered the drugs administered at the time of infection, the association of 1 biologic (more commonly etanercept or adalimumab) plus 1 synthetic DMARD was the most frequently reported (32\% of the cases), followed by methotrexate alone (21\%) and etanercept alone (20.3\%), and finally by the association of either 1 biologic plus 1 synthetic DMARD plus systemic glucocorticoids (9\%) or 1 synthetic DMARD plus systemic glucocorticoids (3.7\%).

\section{Step 4: Analysis of the infections according to MedDRA dictionary}

The evaluation of the Pharmachild registry conducted by the SAC led to the adjudication of the 682 infections corresponding to 53 HLTs and 153 PTs. For 92 (60\%) PTs, the expert committee confirmed the same PT used by the Pharmachild Medical Monitor, while for the remaining $40 \%$, discrepancies were solved by the study SC after re-evaluation of the individual cases. The final number of HLTs was 50, with corresponding 149 PTs, showed in details with the frequency of the events in the additional table 1 .

\section{Step 5: Final evidence-based listing of opportunistic pathogens/infection presentations}

After matching the adjudicated events with the provisional list of OI, among the 682 events, 106 (15.5\%) for 22 PT were classified as "confirmed OI," 274 (40.2\%) for 89 PT were classified as "confirmed non-OI," and 302 (44.3\%) for $38 \mathrm{PT}$ were classified as "possible/patient and/or pathogen- related OI."

Table 4 shows the frequency of the 106 "confirmed OI" by HLT/PT in 93 patients. Regarding pathogens, herpes viral infections resulted the most frequent HLT/ PT category, with 72 events (68\% of the total confirmed OI), mostly represented by herpes zoster infection (66/ 72, 91.6\%). Among the 64 patients with 72 confirmed herpes zoster infections, 35/64 (54.7\%) had varicella in the past history and later developed herpes zoster (34 patients) and herpes zoster oticus (1 patient). One out of 35 patients, who had been vaccinated against varicella zoster had varicella in the past, and later zoster infection. Two additional patients had been vaccinated for varicella among those who developed zoster infection without having varicella reported in the history. Tuberculosis, Candida, papilloma, and Pneumocystis followed with a frequency higher than $3 \%$. Among the 4 papilloma viral infections, affecting 2 patients in their history, no one was preceded by HPV vaccination. Of all the $29 \mathrm{Myco-}$ bacterium tuberculosis infections in Pharmachild (additional table 1), only 11/29 (38\%) were "confirmed OI," mostly in female patients (70\%), at a median age of 5.2 years, not previously vaccinated with BCG, with 
Table 1 Provisional list of pathogens/presentations and MedDRA HLT term approved by consensus by the SAC

Opportunistic infections definitions/pathogens
Definition of definite opportunistic infection in children with JIA
1. Generally does not occur in the absence of immunosuppression and whose presence suggests
a severe alteration in host immunity OR
2. Can occur in patients without recognized forms of immunosuppression, but whose presence
indicates a potential or likely alteration in host immunity

\section{List of definite pathogens and/or presentations of specific pathogens}

Aspergillosis (invasive disease only)

Bartonellosis (disseminated disease only)

BK virus disease including PVAN

Blastomycosis

Candidiasis (invasive disease or pharyngeal)

Coccidioidomycosis

Cryptococcosis

Cytomegalovirus disease with onset at age > 1 month: pneumonia (CMV in BAL), colitis, CNS disease (CMV in CSF), liver (biopsy), retina (confirmed by ophthalmologist), nephritis, myocarditis, pancreatitis

HBV reactivation

Herpes simplex (invasive disease only)

Herpes zoster (any form)

Histoplasmosis

Legionellosis

Listeria monocytogenes (invasive disease only)

Nocardiosis

Non-tuberculous mycobacterium disease

Other invasive fungi: Mucormycosis (zygomycosis) (Rhizopus, Mucor and Lichtheimia), Scedosporium IPseudallescheria boydii, Fusarium

Pneumocystis jirovecii

Post-transplant lymphoproliferative disorder (EBV)

Progressive multifocal leucoencephalopathy

Salmonellosis (invasive disease only)

Strongyloides (hyperinfection syndrome and disseminated forms only)

Toxoplasmosis of central nervous system, onset at age $\geq 1$ month; Disseminated toxoplasmosis, visceral toxoplasmosis

Tuberculosis

\section{Definition of probable opportunistic infection}

Published data is currently lacking, but expert opinion believes that risk is likely elevated in the setting of DMARD therapy. In case of the unusually severe course of infection due to a common pathogen with usually mild disease the pathogen might tentatively be considered opportunistic in a patient with impaired immune function. Below there is a non-exhaustive list of possible pathogens

\section{List of probable pathogens and/or presentations of specific pathogens}

Campylobacteriosis (invasive disease only)

Cryptosporidium species (chronic disease only)

\section{Enterovirus chronic encephalitis}

Giardia, Isospora: chronic (> 1 month) diarrhea

HCV progression

Human Herpes Virus (HHV6-7): pneumonia, encephalitis

Human Herpes Virus (HHV8): kaposi sarcoma
MedDRA HLT

\author{
Aspergillus infections \\ Bartonella infections \\ BK virus infection \\ Blastomyces infections \\ Candida infections \\ Coccidioides infections/Paracoccidioides \\ infections \\ Cryptococcal infections \\ Cytomegaloviral infections
}

Hepatitis viral infections

Herpes viral infections

Herpes viral infections

Histoplasma infections

Legionella infections

Listeria infections

Nocardia infections

Atypical mycobacterial infections

Fungal infections NEC

Pneumocystis infections

Epstein-Barr viral infections

Polyomavirus infections

Salmonella infections

Nematode infections

Toxoplasma infections

Tuberculous infections
Campylobacter infections
Cryptosporidia infections
Enteroviral infections NEC
Giardia infections/lsospora infections
Hepatitis viral infections
Herpes viral infections
Herpes viral infections 
Table 1 Provisional list of pathogens/presentations and MedDRA HLT term approved by consensus by the SAC (Continued)

\begin{tabular}{ll}
\hline Opportunistic infections definitions/pathogens & MedDRA HLT \\
\hline Human metapneumovirus (hMPV): pneumonia, ARDS & Viral infections NEC \\
Human Papilloma Virus (HPV): extensive warts & Papilloma viral infections \\
Human respiratory syncytial virus (RSV): pneumonia with onset > $\mathbf{6}$ months of age & Respiratory syncytial viral infections \\
Legionellosis & Legionella infections \\
Leishmaniasis (Visceral only) & Leishmania infections \\
Microsporidiosis & Protozoal infections NEC \\
Molluscum contagiosum: chronic, disseminated & Molluscum contagiosum \\
Paracoccidioides infections & Paracoccidioides infections \\
Parvovirus B19: pure red cell aplasia & Parvoviral infections \\
Penicillium marneffei & Fungal infections NEC \\
Rota-Arena-Norovirus: chronic (> 1 month) diarrhea & Rotaviral infections/Arenaviral \\
Shigellosis (invasive disease only) & infections/Caliciviral infections \\
Sporothrix schenckii & Shigella infections \\
Trypanosoma cruzi infection (Chagas' disease) (disseminated disease only) & Sporothrix infections \\
Varicella: encephalitis (excluding cerebellitis), hepatitis, pneumonia & Trypanosomal infections \\
Vibriosis (invasive disease due to Vibrio vulnificus) & Herpes viral infections \\
West Nile, Usutu: chronic encephalitis & Vibrio infections
\end{tabular}

In bold, those pathogens/presentations modified by the Safety Adjudication Committee (SAC) after consensus and literature review on the basis of Winthrop et al.'s paper [32]. PVAN polyomavirus-associated nephropathy, BAL bronchoalveolar lavage, CNS central nervous system, CSF cerebrospinal fluid, DMARD diseasemodifying anti-rheumatic drug, CMV cytomegalovirus

pulmonary or disseminated presentations. The remaining were either latent tuberculosis or not wellspecified contact with the pathogen, classified by the SAC as "possible/patient and/or pathogen-related OI." The majority of the "confirmed OI" was reported in Europe $(75.5 \%)$, while $11.3 \%$ was reported in Russia, $9.4 \%$ in Brazil, and $1.9 \%$ in India and Israel. These events occurred after a median period of 5.3 years from disease onset (IQR 3.4-9.2). Scanty data were reported on the immune status of the patients with "confirmed OI" at the moment of infection and soon afterwards. For $17.8 \%$ (10/93) of the patients with "confirmed OI," there was evidence of lymphocytes below $500 / \mu$ l only in 2 patients with cytomegalovirus and herpes zoster infection. No other immunological abnormalities could be observed (data not shown).

When we considered the most frequent "confirmed OI," namely herpes zoster infections, Candida infections, and HPV infections, we noticed that patients were mostly female, with a median age at event onset between 5 and 6 years, except for HPV infection, with a median age at the event onset during adolescence (median 14.5 years, IQR 11.9-17.1).

The most frequent "confirmed OI," herpes zoster and tuberculosis, occurred in the majority of the cases, during treatment with biologics $(70.8 \%$ and $90.9 \%$, respectively) and methotrexate (56.9\% and $90.9 \%$, respectively), followed by systemic glucocorticoids (19.4\% and 27.3\%, respectively). For Candida, glucocorticoids were reported in half of the cases, followed by biologics. By excluding one patient who got one steroid pulse at high dose and developed disseminated tuberculosis, the remaining patients with "confirmed OI" received a median dose of prednisone of $15 \mathrm{mg} /$ day concomitantly to the infection. Details on the remaining infections can be found in the additional table 2 .

Table 5 reports the frequency of "confirmed non-OI" and "possible/patient and/or pathogen-related OI," after removing 218 infections for which PTs did not include a specific pathogen (the complete list of "confirmed nonOI" and "possible/patient and/or pathogen- related OI" is presented in additional table 1). Among the 274 infections classified as "confirmed non-OI," only 59 (21.5\%) were related to a specific pathogen, most frequently influenza virus, Streptococcus, Staphylococcus, and Escherichia. Conversely, almost all the infections classified as "possible/patient and/or pathogen-related OI" (299/302, $99 \%)$ were related to a specific pathogen.

Most of the herpes virus infections (193/299, 64.5\%) were classified as "possible patient- and/or pathogenrelated OI" with a different clinical presentation compared to the previous group of "confirmed OI." In particular, varicella was the most common herpetic manifestation in this group, with $155 / 299$ (51.8\%) cases, followed by herpes simplex infections. Epstein-Barr virus infections were reported in $38 / 299$ cases (12.7\%), 
Table 2 Demographic and clinical characteristics of the Pharmachild patients with infections

\begin{tabular}{|c|c|c|c|c|}
\hline $\begin{array}{l}\text { Data are } n(\%) \text { or medians } \\
\text { with IQR range }\end{array}$ & $\begin{array}{l}\text { Patients adjudicated* } \\
(N=572)\end{array}$ & $\begin{array}{l}\text { Patients not } \\
\text { adjudicated }^{*}(N=323)\end{array}$ & $\begin{array}{l}\text { Patients with } \\
\text { infections }(N=895)\end{array}$ & $\begin{array}{l}P \text { (patients adjudicated } \\
\text { vs not adjudicated) }\end{array}$ \\
\hline Females & $388(67.8 \%)$ & $241(74.6 \%)$ & $629(70.3 \%)$ & 0.033 \\
\hline Age at onset & $3.1(1.7-6.7)$ & $4.1(2.1-8.5)$ & $3.5(1.9-7.3)$ & 0.001 \\
\hline Age at JIA diagnosis & $3.7(2.1-7.5)$ & $4.9(2.4-9.5)$ & $4.1(2.2-8.1)$ & 0.001 \\
\hline Disease duration at last FU & $7.6(5.0-11.1)$ & $5.8(3.1-10.3)$ & $7.1(4.2-10.8)$ & $<0.001$ \\
\hline JIA category & & & & 0.004 \\
\hline Systemic & $120(20.9 \%)$ & $37(11.4 \%)$ & $157(17.5 \%)$ & \\
\hline Oligo persistent & $101(17.7 \%)$ & $80(24.8 \%)$ & $181(20.2 \%)$ & \\
\hline Oligo extended & $100(17.5 \%)$ & $50(15.5 \%)$ & $150(16.8 \%)$ & \\
\hline Polyarticular RF- & $132(23.1 \%)$ & $84(26.0 \%)$ & $216(24.1 \%)$ & \\
\hline Polyarticular RF+ & $19(3.3 \%)$ & $15(4.6 \%)$ & $34(3.8 \%)$ & \\
\hline Psoriatic & $25(4.4 \%)$ & $8(2.5 \%)$ & $33(3.7 \%)$ & \\
\hline Enthesitis & $36(6.3 \%)$ & $21(6.5 \%)$ & $57(6.4 \%)$ & \\
\hline Undifferentiated & $39(6.8 \%)$ & $28(8.7 \%)$ & $67(7.5 \%)$ & \\
\hline Systemic glucocorticoids & $336(58.7 \%)$ & $154(47.7 \%)$ & $490(54.7)$ & 0.001 \\
\hline \multicolumn{5}{|l|}{ Synthetic DMARDs } \\
\hline Methotrexate & $532(93.0 \%)$ & $289(89.5 \%)$ & $821(91.7 \%)$ & $\begin{array}{l}0.065 \\
<0.001\end{array}$ \\
\hline Cyclosporine & $90(15.7 \%)$ & $13(4.1 \%)$ & $103(11.5 \%)$ & $<0.001$ \\
\hline Sulfasalazine & $66(11.5 \%)$ & $28(8.7 \%)$ & $94(10.5 \%)$ & 0.179 \\
\hline Leflunomide & $40(7.0 \%)$ & $28(8.7 \%)$ & $68(7.6 \%)$ & 0.364 \\
\hline Azathioprine & $17(3.0 \%)$ & $6(1.9 \%)$ & $23(2.6 \%)$ & 0.312 \\
\hline Hydroxychloroquine & $14(2.4 \%)$ & $9(2.8 \%)$ & $23(2.6 \%)$ & 0.758 \\
\hline Thalidomide & $7(1.2 \%)$ & $2(0.6 \%)$ & $9(1.0 \%)$ & 0.501 \\
\hline \multicolumn{5}{|l|}{ Biologic DMARDs } \\
\hline Etanercept & $298(52.1 \%)$ & $126(39.0 \%)$ & $424(47.4 \%)$ & $<0.001$ \\
\hline Adalimumab & $178(31.1 \%)$ & $82(25.4 \%)$ & $260(29.1 \%)$ & 0.070 \\
\hline Tocilizumab & $103(18.0 \%)$ & 19 (5.9\%) & $122(13.6 \%)$ & $<0.001$ \\
\hline Infliximab & $84(14.7 \%)$ & $17(5.3 \%)$ & $101(11.3 \%)$ & $<0.001$ \\
\hline Anakinra & $54(9.4 \%)$ & $28(8.7 \%)$ & $82(9.2 \%)$ & 0.701 \\
\hline Abatacept & $39(6.8 \%)$ & $17(5.3 \%)$ & $56(6.3 \%)$ & 0.356 \\
\hline Canakinumab & $28(4.9 \%)$ & $10(3.1 \%)$ & $38(4.2 \%)$ & 0.200 \\
\hline Rituximab & $26(4.5 \%)$ & $3(0.9 \%)$ & $29(3.2 \%)$ & 0.003 \\
\hline Golimumab & $14(2.4 \%)$ & $6(1.9 \%)$ & $20(2.2 \%)$ & 0.566 \\
\hline Certolizumab & $4(0.7 \%)$ & $1(0.3 \%)$ & $5(0.6 \%)$ & 0.453 \\
\hline Other biologic agents & $2(0.3 \%)$ & $1(0.3 \%)$ & $3(0.3 \%)$ & 1.000 \\
\hline
\end{tabular}

Data are $n(\%)$ or medians with IQR range. Drugs refer to their administration at any time during the patient's history and are sorted by their descending frequencies. *The adjudicated patients are represented by those with opportunistic infections as per the provisional list of opportunistic pathogens/presentations (step 1), and very severe/severe or serious non-opportunistic infections. The remaining ones represent the not adjudicated patients. JIA juvenile idiopathic arthritis, FU follow-up, RF rheumatoid factor, DMARDs disease-modifying anti-rheumatic drugs

classified as infectious mononucleosis in 13 cases $(4.3 \%)$. Latent tuberculosis accounted for $12 / 299$ (4.1\%) cases, followed by a few cases of tuberculosis, also with lymph node involvement included in this group. The remaining events of "possible/patient and/or pathogen-related OI" affected less than $3 \%$ of the cases.

\section{Discussion}

An evidence-based list of opportunistic pathogens with the related MedDRA classification in immunosuppressed children with JIA has been derived by the combination of consensus among a panel of pediatricians with expertise in rheumatology and infectious diseases, and the analysis of the Pharmachild international registry in JIA 
Table 3 Frequency of answers by the SAC. Consensus by the majority of the Safety Adjudication Committee (SAC) members (3/5) was required on the first 3 questions, so that 689 events were adjudicated by the panel. Among them, 682 were confirmed as infections and retained for the analysis

\begin{tabular}{|c|c|c|c|c|}
\hline Question for adjudication by the SAC & Yes & No & Impossible to determine & Total with consensus \\
\hline $\begin{array}{l}\text { 1. Based on the information provided, do you confirm } \\
\text { that this patient had an infection? }\end{array}$ & $682(99 \%)$ & 0 & $7(1 \%)$ & $689(100 \%)$ \\
\hline 2. Is this infection common? & $603(88.4 \%)$ & $78(11.4 \%)$ & $1(0.2 \%)$ & $682(100 \%)$ \\
\hline 3. Is this an opportunistic infection? & $119(17.4 \%)$ & $556(81.5 \%)$ & $7(1 \%)$ & $682(100 \%)$ \\
\hline 4. Was the treatment appropriate for the infection? & $484(77.1 \%)$ & $4(0.6 \%)$ & $140(22.3 \%)$ & $628(92 \%)$ \\
\hline $\begin{array}{l}\text { 5. Could the event be possibly related to any of the } \\
\text { drug(s) taken at the time of the event? }\end{array}$ & $307(76.2 \%)$ & $70(17.4 \%)$ & $2(0.5 \%)$ & $403^{*}(59 \%)$ \\
\hline
\end{tabular}

${ }^{*} n=24$ were events without answers for the lack of consensus by the panel (less than $3 / 5$ experts agreeing on the answer)

[39]. The final list of opportunistic infections/presentations could constitute a future reference for researchers, pharmaceutical companies, and regulatory authorities dealing with pharmacovigilance issues.

The introduction of biologics in the 2000s for the treatment of JIA has dramatically changed the prognosis of children affected by JIA, but has also raised concerns on the possible risk of infections and other safety events in these patients. Despite the widespread use of these drugs, there is still a lack of knowledge regarding the assessment of the long-term safety of the biologics in JIA. In this context, the role of national and international registries becomes an important source of data [39, 45-47].

The Pharmachild international registry has the advantage of combining information from different countries based on real clinical data. In Pharmachild, infections occurred in about $11 \%$ of patients with JIA [39], and among them, it is of primary importance to identify the opportunistic infections that may impose a serious threat to the immunocompromised child. This is not an easy task, because apparently there is a large gap between what treating pediatric rheumatologists feel can be considered as an OI and what a panel of experts adjudicates as such. While most serious infections also occur in the healthy population, some events are more frequent or severe in case of immunosuppression. Conversely, some infections, such as tuberculosis, more common in immunocompromised children, may affect also the general population, although usually less severely [48]. Considering these difficulties in correctly defining OI, we made an effort to produce a document defining OI specifically in children with JIA on immunosuppression. Something similar was recently developed by a specialized Committee convened in the adult setting to define OI in adults and children with immune-mediated diseases on biologics [32]. With the same approach, our panel of specialists voted, through a three-step Delphi procedure, for a correct definition of definite and probable OI and subsequently produced a list of OI by cross-matching the provisional list produced by consensus with the Pharmachild data. In a first phase of our study, among the
Pharmachild patients, a considerable percentage of infections $(119 / 682,17.4 \%)$ was adjudicated as opportunistic. When we matched the provisional list of OI with the patients' clinical information, it became clear that other than events with full agreement between the SAC and the list, which could be considered either "confirmed OI" (106/682, 15.5\%) or "non-confirmed OI" (274/682, $40.2 \%)$, there was a considerable number (299/682, $43.8 \%$ ) of debatable infections due to the specific patient's history and/or the pathogen presentation, and classified as "possible/patient and/or pathogen-related OI." The best example is represented by herpes zoster (Tables 4 and 5). Varicella zoster presentation was included among the "confirmed OI," as suggested in the majority of the literature in this issue [49-51]. However, primary varicella infection, frequently observed in our population $(155 / 682,22.7 \%)$, was included among the "possible/patient and/or pathogen-related OI" rather than "definite OI" due to the high incidence in healthy non-vaccinated children and its usually non-complicated presentation. This group of patients highlights the difficulties in defining OI in children with JIA on treatment, but also the critical importance of providing a reference document listing those infections that should always be considered as opportunistic in these patients, with possible implications for treatment or prophylaxis. Half of the patients with herpes zoster infections had varicella in their history indicating a possible subsequent reactivation of the virus due to a transient immunosuppressive condition. One patient developed varicella despite vaccination while 2 patients had herpes infection despite previous vaccination, without manifesting primary varicella. This observation may give rise to speculations about a possible increase in zoster infections in JIA population under immunosuppressive therapy through varicella infection as well as herpes zoster reactivation. Limited data are available on vaccinations for other infections such as papillomavirus, which occurred only in 2 patients not previously vaccinated. Therefore, it would be worthwhile to develop further studies focused specifically on this topic, in order to understand if 
Table 4 Frequency of the 106 infections classified as "confirmed OI" by the SAC. Opportunistic infections (OI) were classified as "confirmed OI" after the evaluation of the cases available in Pharmachild with full agreement between the Safety Adjudication Committee (SAC) and the list of provisional pathogens/presentations. Data are presented as per the MedDRA High Level and Preferred Term and sorted by frequencies in descending order

\begin{tabular}{|c|c|c|}
\hline HLT-PT name & $\begin{array}{l}\text { "Confirmed Ol" } \\
N=106\end{array}$ & $\begin{array}{l}\text { Patients } \\
N=93^{*}\end{array}$ \\
\hline Herpes viral infections & $72(68 \%)$ & $64(68.8 \%)$ \\
\hline Herpes zoster & $66(91.6 \%)$ & \\
\hline Herpes ophthalmic & $2(2.8 \%)$ & \\
\hline Ophthalmic herpes zoster & $2(2.8 \%)$ & \\
\hline Herpes virus infection & $1(1.4 \%)$ & \\
\hline Herpes zoster oticus & $1(1.4 \%)$ & \\
\hline Tuberculous infections & $11(10.4 \%)$ & $10(10.8 \%)$ \\
\hline Pulmonary tuberculosis & $6(54.5 \%)$ & \\
\hline Disseminated tuberculosis & $4(36.4 \%)$ & \\
\hline Bone tuberculosis & $1(9.1 \%)$ & \\
\hline Candida infections & $9(8.5 \%)$ & $9(9.7 \%)$ \\
\hline Oral candidiasis & $4(44.4 \%)$ & \\
\hline Candida pneumonia & $2(22.2 \%)$ & \\
\hline Balanitis candida & $1(11.1 \%)$ & \\
\hline Candida sepsis & $1(11.1 \%)$ & \\
\hline Esophageal candidiasis & $1(11.1 \%)$ & \\
\hline Papilloma viral infections & $4(3.8 \%)$ & $2(2.2 \%)$ \\
\hline $\begin{array}{l}\text { Vulvovaginal human } \\
\text { papilloma virus infection }\end{array}$ & $3(75 \%)$ & \\
\hline Anogenital warts & $1(25 \%)$ & \\
\hline Pneumocystis infections & $4(3.8 \%)$ & $4(4.3 \%)$ \\
\hline $\begin{array}{l}\text { Pneumocystis jirovecii } \\
\text { pneumonia }\end{array}$ & $4(100 \%)$ & \\
\hline Cytomegaloviral infections & $3(2.8 \%)$ & $3(3.2 \%)$ \\
\hline Cytomegalovirus mononucleosis & $1(33.3 \%)$ & \\
\hline Cytomegalovirus viraemia & $1(33.3 \%)$ & \\
\hline Pneumonia cytomegaloviral & $1(33.3 \%)$ & \\
\hline Aspergillus infections & $1(0.9 \%)$ & $1(1.1 \%)$ \\
\hline Bronchopulmonary aspergillosis & $1(100 \%)$ & \\
\hline Leprous infections & $1(0.9 \%)$ & $1(1.1 \%)$ \\
\hline Leprosy & $1(100 \%)$ & \\
\hline Infections NEC & $1(0.9 \%)$ & $1(1.1 \%)$ \\
\hline $\begin{array}{l}\text { Infection in an } \\
\text { immunocompromised host }\end{array}$ & $1(100 \%)$ & \\
\hline
\end{tabular}

*One patient may have been suffering from different Ol over time

vaccinations may maintain a protective immune status in JIA patients under treatment or not. It would also be interesting to investigate how to identify patients with JIA at risk for developing OI, but this would require further comparative studies on the immune status in JIA patients receiving different immunosuppressive treatments. Per definition, a definite OI can occur in patients without recognized forms of immunosuppression but its presence indicates a potential or likely alteration in host immunity. Therefore, it is worthwhile to consider each OI as relevant and representing a potential risk for the JIA patient's life, thus requiring a prompt treatment. In fact, to the best of our knowledge, there are no studies indicating who is at major risk of complications due to an opportunistic pathogen among JIA patients on immunosuppressive therapy. The use of an immune screening to help primary care practitioners who may care for, diagnose, and manage infections is already consolidated in clinical practice [45]. In our study, we found no specific level of immunosuppression indicating an increased frequency of infections such as Pneumocystis jirovecii, although too little data are available on this issue and further analysis is needed to understand the correlation between immune status and OI in patients with autoimmune diseases.

Biologics and methotrexate were often seen at the time of a "confirmed OI." Nevertheless, a comparative study about the role of immunosuppressive drugs would require a larger population and a deeper analysis, which was not the aim of the present manuscript.

Besides those pathogens confirmed as OI and non- or possible OI by the panel on the basis of the Pharmachild real patients' data, there are also pathogens (e.g., Nocardia) that have been included in the list of definite/possible OI (Table 1) by consensus, although they were not identified in Pharmachild. These infections, apparently uncommon since there was none in such a large database, should be considered potential indicators of alterations in host immunity when present in JIA patients and deeply investigated by the physician of the center in order to prevent possible complications in these patients.

The current literature provides similar evidence, but remains controversial for the majority of OI. Beukelman et al. in 2012 reviewed US Medicaid data comparing the incidence of bacterial infections requiring hospitalization in children with and without JIA $[1,30]$. The infection rate was already twice as high in patients with JIA not exposed to treatments, compared to children with attention-deficit hyperactivity disorder (ADHD) used as controls [30]. The same author 1 year later re-analyzed the same data by comparing the incidence rate of selected OI among children with and without JIA. Coccidioides, Salmonella, and herpes zoster were more common among children with JIA [31]. Among the 15 pathogens they used to define their list of OI, all in our provisional OI list (Table 1), only herpes zoster, tuberculosis, Pneumocystis, and Aspergillus were confirmed in 
Table 5 Frequency of the "confirmed non-OI" and "possible/patient and pathogen-related OI" adjudicated by the SAC

\begin{tabular}{|c|c|c|}
\hline $\begin{array}{l}\text { HLT-PT name } \\
N(\%)\end{array}$ & $\begin{array}{l}\text { "Confirmed non-Ol" } \\
N=59(\%)\end{array}$ & $\begin{array}{l}\text { "Possible } \\
N=299\end{array}$ \\
\hline \multicolumn{3}{|c|}{ Herpes viral infections, $N=193$ (64.5) } \\
\hline Varicella & & $128(42.8)$ \\
\hline Oral herpes & & $30(10.1)$ \\
\hline Varicella zoster virus infection & & $24(8.1)$ \\
\hline Other herpes infections & & $11(3.7)$ \\
\hline \multicolumn{3}{|c|}{ Epstein-Barr viral infections, $N=38$ (12.7) } \\
\hline Epstein-Barr virus infection & & $22(7.4)$ \\
\hline Other EBV infections & & $16(5.3)$ \\
\hline \multicolumn{3}{|c|}{ Tuberculous infections, $N=18(6.0)$} \\
\hline Latent tuberculosis & & $12(4.1)$ \\
\hline Tuberculosis & & $6(2.0)$ \\
\hline \multicolumn{3}{|l|}{ Candida infections, $N=8$ (2.7) } \\
\hline Vulvovaginal candidiasis & & $6(2.1)$ \\
\hline Other candidiasis & & $2(0.6)$ \\
\hline
\end{tabular}

Influenza viral infections, $N=14$ (23.7)

$\begin{array}{ll}\text { Influenza } & 13(22) \\ \text { H1N1 influenza } & 1(1.7) \\ \text { Streptococcal infections, } \boldsymbol{N}=\mathbf{1 4}(\mathbf{2 3 . 7 )} & \\ \text { Scarlet fever } & 4(6.7) \\ \text { Pharyngitis streptococcal } & 3(5.1) \\ \text { Other streptococcal infections } & 7(11.9)\end{array}$

Salmonella infections, $N=9$ (3.0)

Gastroenteritis salmonella

Other Salmonella infections

Molluscum contagiosum viral infections, $N=7(2.3)$ (2.3)

Molluscum contagiosum

Staphylococcal infections, $N=5(8.5)$

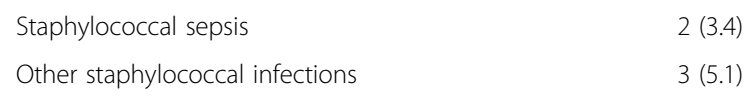

Escherichia infections, $N=4$ (6.8)

Escherichia pyelonephritis 3 (5.1)

Cystitis Escherichia 1 (1.7)

Skin structures and soft tissue infections, $N=3$ (5.1) (5.1)

Impetigo

Bordetella infections, $N=3$ (5.1)

Pertussis

Bordetella infection

Mycoplasma infections, $N=3$ (5.1)

Mycoplasma infections

Yersinia infections, $N=2$ (3.4)

Gastroenteritis yersinia

Other infections (HLT frequency < $2 \%$ )

11 (18.6)

$26(8.7)$

Clinical presentations were removed because of the lack of the specified pathogen. Data are presented as per the MedDRA High Level Term and Preferred Term and sorted by frequencies in descending order. Only pathogens with HLT $\% \geq 2 \%$ are presented in details. The full listing is available in additional table 1. SAC Safety Adjudication Committee 
our final list of "confirmed OI." The remaining cases were included in the "possible/patient and/or pathogenrelated OI" list. Interestingly, the authors included primary varicella infection in the OI only if the affected patient received critical care services during the hospitalization. An increased risk of herpes zoster infection was confirmed in many studies, both in JIA [49] and in adult rheumatoid arthritis [52]. More recently, Aeschlimann et al. studied, through a meta-analysis, whether treatment with biologics during clinical trial study periods increased the risk of serious infections in children with JIA. On a total of 19 trials accounting for 21 individual studies, 17 serious infections were reported among 810 children, with bronchopulmonary infections and varicella being the most frequent events [53]. Besides this evidence, the role of other opportunistic pathogens still needs to be further investigated, as well as the comparison of OI among large registries. Recently, Swart et al. have provided a comparison between Pharmachild and national registries. In particular, a comparable percentage of serious AE has been found between Pharmachild and the German registry Biker $(6.9 \%$ and $7.4 \%$, respectively), with an overlapping frequency of infection and infestations among all AEs (29.4-30.1\%). Infections also resulted the most frequent ESI in both registries (75.3-89\%). Interestingly, among OI, tuberculosis affected 27 cases in Pharmachild and none in BiKer, although this could be explained by the different geographic distribution of the patients [39].

A limitation of our study is that Pharmachild is mainly a European registry, although it includes countries worldwide. This means that our results mainly depict the European scenario of OI. A future manuscript will focus on those factors increasing the risk of OI through appropriate modeling to identify the risk factor for OI infection including disease duration, drugs, comorbidities, etc.

\section{Conclusions}

In conclusion, almost 1/5 of all severe and/or serious infections in JIA patients on immunosuppressive therapy are opportunistic. The most frequent opportunistic pathogens were herpes virus (excluding non-complicated primary varicella), mycobacterial, and Candida infections. We provided with our work a list of "confirmed OI" in children with JIA on immunosuppressive therapy that could be used as possible reference document for future works on pharmacovigilance in children with JIA on immunosuppressive therapy and a list of infections that could possibly display an opportunistic nature related to the patient's history and/or the pathogen presentation. More clarity in the understanding of OI in children with JIA on immunosuppressant will help in deciding on immunosuppressive treatment and prophylaxis in this group of patients.

\section{Supplementary information}

Supplementary information accompanies this paper at https://doi.org/10. 1186/s13075-020-02167-2.

\section{Additional file $\mathbf{1}$ figure. Flowchart of the process. \\ Additional file $\mathbf{2}$ figure. Hierarchy of MedDra clinically-validated inter-} national medical terminology.

Additional file $\mathbf{3}$ Table $\mathbf{1}$. Complete table with the frequency of the 682 infections adjudicated by the SAC. Infections were reported after evaluation of the cases available in Pharmachild compared to the pathogens/presentations in the provisional list approved by the Safety Adjudication Committee (SAC). Data are presented as per the MedDRA High Level Term (HLT) and Preferred Term (PT) sorted by frequencies in descending order (HLT and then PT). *For definition see Step 5.

Additional file 4 Table 2. Concomitant medications administered at the time of "confirmed Ol". Bio: biologic, mtx: methotrexate; ste: systemic steroids; sDMARDs: synthetic disease modifying antirheumatic drugs; ${ }^{*}$ SDMARDs are intendend other than MTX.

\section{Abbreviations}

Ol: Opportunistic infections; JIA: Juvenile idiopathic arthritis; SAC: Safety Adjudication Committee; MedDRA: The Medical Dictionary for Regulatory Activities; DMARDs: Disease-modifying anti-rheumatic drugs; FDA: Food and Drug Administration; EMA: European Medicines Agency; PRINTO: Paediatric Rheumatology INternational Trials Organization; PReS: Paediatric

Rheumatology European Society; AE: Adverse events; SAE: Serious adverse events; PT: Preferred term; SC: Steering Committee; SOC: System Organ Class; ESI: Events of Special Interest; SOP: Standard operating procedure;

ILAR: International League Against Rheumatism; HLT: High Level Term; IQR: Inter-quartile range; ADHD: Attention-deficit hyperactivity disorder

\section{Acknowledgements}

We thank all PRINTO centers which contributed to the data collection. From: Argentina: Ruben Cuttica, MD, Buenos Aires and Stella Maris Garay, MD, La Plata. Austria: Jurgen Brunner, MD, Innsbruck and Wolfgang Emminger, MD, Vienna. Brazil: Simone Appenzeller, MD, Campinas, Claudio Len, MD, Sao Paulo and Claudia Saad Magalhaes, MD, Botucatu. Bulgaria: Albena Telcharova - Mihaylovska, MD, Sofia. Croatia: Miroslav Harjacek, MD, Zagreb and Marija Jelusic, MD, Zagreb. Denmark: Anne Estmann, MD, Odense and Susan Nielsen, MD, Copenhagen. Ecuador: Cristina Herrera Mora, MD,

Guayaquil. France: Elisabeth Gervais, MD, Poitiers, Isabelle Koné-Paut, MD, Le Kremlin Bicêtre (Paris) and Pierre Quartier, MD, Paris. Germany: Ivan Foeldvari, MD, Hamburg, Gerd Horneff, MD, Sankt Augustin, Thomas Lutz, MD, Heidelberg, Kirsten Minden, MD, Berlin and Nikolay Tzaribachev, MD, Bad Bramstedt. Greece: Maria Trachana, MD, Thessaloniki, Elena Tsitsami, MD, Athens and Olga Vougiouka, MD, Athens. Hungary: Ilonka Orban, MD, Budapest. Israel: Liora Harel, MD, Petah Tikva, Philip (Pinchas) Hashkes, MD, Jerusalem and Yosef Uziel, MD, Kfar Saba. Italy: Rolando Cimaz, MD, Firenze, Adele Civino, MD, Lecce, Rita Consolini, MD, Pisa, Gianfranco D'Angelo, MD, Ancona, Fabrizio De Benedetti, MD, Rome, Giovanni Filocamo, MD, Milano, Elena Fueri, MD, Genova, Romina Gallizzi, MD, Messina, Maria Cristina Maggio, MD, Palermo, Maria Greca Magnolia, MD, Ciconia - Orvieto (TR), Angela Miniaci, MD, Bologna, Davide Montin, MD, Torino, Alma Nunzia Olivieri, MD, Naples, Serena Pastore, MD, Trieste, Donato Rigante, MD, Roma and Francesco Zulian, MD, Padova. Latvia: Ingrida Rumba-Rozenfelde, MD, Riga and Valda Stanevicha, MD, Riga. Lithuania: Violeta Panaviene, MD, Vilnius. Mexico: Ana Luisa Rodriguez Lozano, MD, Mexico City, Nadina Rubio-Perez, MD, Monterrey NL and Gabriel Vega Cornejo, MD, Guadalajara. Netherlands: Esther Hoppenreijs, MD, Nijmegen, and Sylvia Kamphuis, MD, Rotterdam. Norway: Berit Flato, MD, Oslo and Ellen Berit Nordal, MD, Tromso. Oman: Reem Abdwani, MD, Muscat. Peru: Tatiana Miraval, MD, Lima and Maria Eliana Paz Gastanaga, MD, Lima. Poland: Elzbieta Smolewska, MD, Lodz. Romania: Constantin Ailioaie, MD, lasi, Alexis-Virgil Cochino, MD, Bucharest, Matilda Laday, MD, Tirgu-Mures and Calin Lazar, MD, Cluj-Napoca. Russian Federation: Ekaterina Alexeeva, MD, Moscow, Vyacheslav Chasnyk, MD, Saint- 
Petersburg and Vladimir Keltsev, MD, Togliatti. Saudi Arabia: Wafaa Mohammed Saad Suwairi, MD, Riyadh. Serbia: Gordana Vijatov-Djuric, MD, Novi Sad and Jelena Vojinovic, MD, Nis. Singapore: Thaschawee Arkachaisri, MD, Singapore. Slovakia: Elena Koskova, MD, Piestany. Slovenia: Tadej Avcin, MD, Ljubljana. South Africa: Mahmood Ally, MD, Pretoria, Christa Janse Van Rensburg, MD, Pretoria and Ingrid Louw, MD, Cape Town. Spain: Jordi Anton Lopez, MD, Esplugues de Llobregat, Barcelona, Alina Lucica Boteanu, MD, Madrid, Inmaculada Calvo Penades, MD, Valencia, Jaime De Inocencio, MD, Madrid, Pablo Mesa-del-Castillo, MD, Murcia, Estefania Moreno, MD, Barcelona and Agustin Remesal, MD, Madrid. Switzerland: Michael Hofer, MD, Lausanne. Turkey: Faysal Gok, MD, Ankara and Seza Ozen, MD, Ankara. United Kingdom: Athimalaipet Ramanan, MD, Bristol.

We also thank Chiara Pallotti, MA and Luca Villa, MA PRINTO research assistants for their help in the adjudication process.

\section{Authors' contributions}

GG and NR made substantial contributions to the conception of the work and drafted the first and subsequent versions of the manuscript. JS, GG, FB, $A P, N R, N W$, and $A M$ contributed to the planning of the study. GG, NR, EC, AHG, GH, HIH, DJL, and TW interpreted the data. TH, PD, HS, GS, FS, DM, TC, W, SS, MR, SKO, and MC made substantial contributions to the acquisition of the data.

All authors have approved the submitted version and have agreed both to be personally accountable for the author's own contributions and to ensure that questions related to the accuracy or integrity of any part of the work, even ones in which the author was not personally involved, are appropriately investigated, resolved, and the resolution documented in the literature.

\section{Funding}

Pharmachild has been supported by a grant from the European Union (grant 260353) and by funding from the IRCCS G. Gaslini.

\section{Availability of data and materials}

Pharmachild registry is registered at Clinicaltrials.gov (NCT01399281) and at the European Network of Centres for Pharmacoepidemiology and Pharmacovigilance (ENCePP; http://www.encepp.eu/encepp/viewResource. htm?id=19362).

\section{Ethics approval and consent to participate}

All registries and participating centers obtained approval from their respective ethics committee and obtained consent/assent based on national existing regulations.

\section{Consent for publication \\ Not applicable}

\section{Competing interests}

GG declares that she has no competing interests.

JFS has received sponsorship for a meeting by Sobi $(<\$ 10,000$ USD)

EC declares that he has no competing interests.

AHG has received research grants from Gilead, Merck, Sharp \& Dohme, and

Pfizer; is or has been a consultant to Amplyx, Astellas, Basilea, F2G, Gilead,

Merck, Sharp \& Dohme, and Pfizer; and served at the speakers' bureau of

Astellas, Basilea, Gilead, Merck, Sharp \& Dohme, Pfizer, and Schering-Plough.

All of the above is $<10.000$ per entity.

$\mathrm{GH}$ has received consultancies, speaking fees, and honoraria from Abbvie,

Chugai, Pfizer, Novartis, Roche, and Sanofi ( $<\$ 10,000$ USD each).

$\mathrm{HIH}$ declares that he has no competing interests.

DJL has served on speaker bureaus for Genentech and Bristol-Meyers Squibb and served on a data and safety monitoring boards for Forest Research and the NIH-NIAMS; the Cincinnati Children's Hospital Medical Center has received consulting fees for the work of Dr. Lovell from AbbVie, AstraZeneca, Bristol-Myers Squibb, Centocor, Genentech, Hoffman-La Roche, Lilly, Janssen, Novartis, Pfizer, Regeneron, R-Pharm and UBC. Each activity is less than $\$ 10,000$.

TW declares that he has no competing interests. $\mathrm{TH}$ declares that he has no competing interests.

PD has received speaker's fees or consultancies or travel grants (all $<10,000$ USD) from Medac, Novartis, Abbvie, Roche, SOBI, and Lilly.

$\mathrm{HS}$ declares that she has no competing interests.
GS has received honoraria as a sub-investigator in a Pfizer trial (>10,000 USD).

FS declares that he has no competing interests.

DM declares that she has no competing interests.

$\mathrm{TC}$ has received consultancies, speaking fees, and honoraria from Roche and Abbvie $<\$ 10,000$.

$W$ has received consultancies, speaking fees, and honoraria from Pfizer, Abbvie, and Sobi $(<\$ 10,000)$.

SS declares that she has no competing interests. MR declares that she has no competing interests. SKO has received teaching honoraria from Pfizer $(<\$ 10,000)$.

MC declares that he has no competing interests.

FBo received teaching honoraria from Novartis $(<\$ 10,000)$ and consulting fees from Biogen $(<\$ 10,000)$.

FBa declares that she has no competing interests.

AP declares that she has no competing interests.

AM: starting from 1 March 2016 to December 2018 Prof. Alberto Martini did not have any conflict of interest to declare since he was the Scientific Director of IRCCS Istituto Gaslini and this role did not allow him to render private consultancies resulting in personal income. He performed consultancy activities on behalf of the Gaslini Institute for the following companies: Abbvie, Biogen, Boehringer, Bristol-Myers and Squibb, EMD Serono, Janssen, Novartis, Pfizer, and R-Pharm. The money received for these activities was directly transferred to the Gaslini Institute's bank account. Since January 2019, Prof. Alberto Martini is no longer the Scientific Director of IRCCS Istituto Gaslini; therefore, he can perform private consultancy services. Currently, he has active consultancy agreements with Janssen, Novartis, and Pfizer (< 10.000 USD each).

NW has received an institutional research grant from AbbVie (> 10,000 USD) for an e-health project. Consultancies: BMS (<10,000 USD) on e-health developments.

NR has received honoraria for consultancies or speaker bureaus $(<10.000$ USD each) from the following pharmaceutical companies in the past 3 years: Ablynx, AbbVie, Astrazeneca-Medimmune, Biogen, Boehringer, Bristol-Myers and Squibb, Eli-Lilly, EMD Serono, Glaxo Smith and Kline, Hoffmann-La Roche, Janssen, Merck, Novartis, Pfizer, R-Pharma, SanofiServier, Sinergie, Sobi, and Takeda. The Gaslini Hospital, where NR works as full-time public employee, has received contributions ( $>10.000$ USD each) from the following industries in the last 3 years: BMS, Eli-Lilly, GlaxoSmithKline, F Hoffmann-La Roche, Janssen, Novartis, Pfizer, and Sobi. This funding has been reinvested for the research activities of the hospital in a fully independent manner, without any commitment with third parties.

\section{Author details}

${ }^{1}$ IRCCS Istituto Giannina Gaslini, Clinica Pediatrica e Reumatologia, PRINTO, Genoa, Italy. ${ }^{2}$ Department of Pediatric Immunology and Rheumatology, Wilhelmina Children's Hospital, University Medical Center Utrecht, University Utrecht, European Reference Network-RITA, Utrecht, The Netherlands. ${ }^{3}$ Department of Infectious Diseases, IRCCS Istituto Giannina Gaslini, Genoa, Italy. ${ }^{4}$ Infectious Disease Research Program, Department of Pediatric Hematology and Oncology, University Children's Hospital, Münster, Germany. ${ }^{5}$ Asklepios Clinic Sankt Augustin, Department of General Paediatrics, Sankt Augustin, Germany. ${ }^{6}$ Medical Faculty, Department of Paediatric and Adolescents Medicine, University Hospital of Cologne, Cologne, Germany. ${ }^{7}$ Clinic Bremen-Mitte, Prof.-Hesse Children's Hospital and Pediatric Intensive Care Medicine, Bremen, Germany. ${ }^{8}$ Division of Rheumatology, Cincinnati Children's Hospital Medical Center, Cincinnati, OH, USA. ${ }^{9}$ Pediatric Rheumatology Unit, Aarhus University Hospital, Aarhus, Denmark. ${ }^{10} 1 \mathrm{st}$ Faculty of Medicine, Department of Pediatrics and Adolescent Medicine, Charles University in Prague and General University Hospital, Praha, Czech Republic. ${ }^{11}$ Department of Rheumatology, Oslo University Hospital, Oslo, Norway. ${ }^{12}$ Norwegian National Advisory Unit on Rheumatic Diseases in Children and Adolescents, Oslo, Norway. ${ }^{13}$ Institute of Rheumatology of Belgrade, Division of Pediatric Rheumatology, Belgrade, Serbia. ${ }^{14} \mathrm{Hospital}$ Universitario Pedro Ernesto, Nucleo de Estudos da Saúde do Adolescente, Universidade do Estado do Rio de Janeiro, Rio de Janeiro, Brazil. ${ }^{15} 2 \mathrm{nd}$ Department of Pediatrics Athens Medical School, National and Kapodistrian University of Athens (NKUA), Athens, Greece. ${ }^{16}$ Unit of Pediatric Rheumatology-Immunology, Second Department of Pediatrics, Semmelweis University, Budapest, Hungary. ${ }^{17}$ Faculty of Medicine, Department of Paediatrics and Adolescent Medicine, Pavol Jozef Šafárik University in Košice, 
Kosice, Slovakia. ${ }^{18}$ Sir Ganga Ram Hospital Marg, Centre for Child Health, Sir Ganga Ram Hospital, New Delhi, India. ${ }^{19}$ Department of Clinical and Molecular Medicine, Faculty of Medicine and Health Sciences, NTNU Norwegian University of Science and Technology, Trondheim, Norway. ${ }^{20}$ Department of Pediatrics, St. Olavs University Hospital of Trondheim, Trondheim, Norway. ${ }^{21}$ Instituto de Puericultura e Pediatria Martagao Gesteira (IPPMG), Universidade Federal do Rio de Janeiro, Rio de Janeiro, Brazil. ${ }^{22}$ Clinica Pediatrica dell'Università di Brescia, Spedali Civili, Unità di Immunologia e Reumatologia Pediatrica, Brescia, Italy. ${ }^{23}$ IRCCS Istituto Giannina Gaslini, Servizio di Epidemiologia e Biostatistica, Genoa, Italy. ${ }^{24}$ Dipartimento di Neuroscienze, Riabilitazione, Oftalmologia, Genetica e Scienze Materno-Infantili (DiNOGMI), Università degli Studi di Genova, Genoa, Italy.

\section{Received: 18 November 2019 Accepted: 27 March 2020} Published online: 07 April 2020

\section{References}

1. Lovell DJ, Giannini EH, Reiff A, Cawkwell D, Silverman ED, Nocton JJ, et al. Etanercept in children with polyarticular juvenile rheumatoid arthritis. $\mathrm{N}$ Engl J Med. 2000;342(11):763-9.

2. Lovell DJ, Reiff A, llowite NT, Wallace CA, Chon Y, Lin SL, et al. Safety and efficacy of up to eight years of continuous etanercept therapy in patients with juvenile rheumatoid arthritis. Arthritis Rheum. 2008;58(5):1496-504.

3. Giannini EH, llowite NT, Lovell DJ, Wallace CA, Rabinovich CE, Reiff A, et al. Effects of long-term etanercept treatment on growth in children with selected categories of juvenile idiopathic arthritis. Arthritis Rheum. 2010; 62(11):3259-64.

4. Horneff G, Burgos-Vargas R, Constantin T, Foeldvari I, Vojinovic J, Chasnyk VG, et al. Efficacy and safety of open-label etanercept on extended oligoarticular juvenile idiopathic arthritis, enthesitis-related arthritis and psoriatic arthritis: part 1 (week 12) of the CLIPPER study. Ann Rheum Dis. 2014;73(6):1114-22.

5. Constantin T, Foeldvari I, Vojinovic J, Horneff G, Burgos-Vargas R, Nikishina I, et al. Two-year efficacy and safety of etanercept in pediatric patients with extended oligoarthritis, enthesitis-related arthritis, or psoriatic arthritis. J Rheumatol. 2016:43(4):816-24.

6. Verazza S, Davi S, Consolaro A, Bovis F, Insalaco A, Magni-Manzoni S, et al. Disease status, reasons for discontinuation and adverse events in 1038 Italian children with juvenile idiopathic arthritis treated with etanercept. Pediatr Rheumatol Online J. 2016;14(1):68.

7. Ruperto N, Lovell DJ, Cuttica R, Woo P, Meiorin S, Wouters C, et al. Long term efficacy and safety of infliximab plus methotrexate for the treatment of polyarticular-course juvenile rheumatoid arthritis: findings from an openlabel treatment extension. Ann Rheum Dis. 2010;69(4):718-22.

8. Lovell DJ, Ruperto N, Goodman S, Reiff A, Jung L, Jarosova K, et al. Adalimumab with or without methotrexate in juvenile rheumatoid arthritis. N Engl J Med. 2008;359(8):810-20.

9. Ruperto N, Lovell DJ, Quartier P, Paz E, Rubio-Perez N, Silva CA, et al. Abatacept in children with juvenile idiopathic arthritis: a randomised, double-blind, placebo-controlled withdrawal trial. Lancet. 2008;372(9636): 383-91.

10. Ruperto N, Lovell DJ, Quartier P, Paz E, Rubio-Perez N, Silva CA, et al. Longterm safety and efficacy of abatacept in children with juvenile idiopathic arthritis. Arthritis Rheum. 2010;62(6):1792-802.

11. Lovell DJ, Ruperto N, Mouy R, Paz E, Rubio-Perez N, Silva CA, et al. Longterm safety, efficacy, and quality of life in patients with juvenile idiopathic arthritis treated with intravenous abatacept for up to seven years. Arthritis Rheumatol. 2015;67(10):2759-70.

12. De Benedetti F, Brunner HI, Ruperto N, Kenwright A, Wright S, Calvo I, et al. Randomized trial of tocilizumab in systemic juvenile idiopathic arthritis. $\mathrm{N}$ Engl J Med. 2012;367(25):2385-95

13. Brunner HI, Ruperto N, Zuber Z, Keane C, Harari O, Kenwright A, et al. Efficacy and safety of tocilizumab in patients with polyarticular-course juvenile idiopathic arthritis: results from a phase 3, randomised, doubleblind withdrawal trial. Ann Rheum Dis. 2015;74(6):1110-7.

14. Ruperto N, Brunner HI, Quartier P, Constantin T, Wulffraat N, Horneff G, et al. Two randomized trials of canakinumab in systemic juvenile idiopathic arthritis. N Engl J Med. 2012;367(25):2396-406.

15. Brunner HI, Ruperto N, Tzaribachev N, Horneff G, Chasnyk VG, Panaviene V, et al. Subcutaneous golimumab for children with active polyarticular-course juvenile idiopathic arthritis: results of a multicentre, double-blind, randomised-withdrawal trial. Ann Rheum Dis 2017 May 15; [Epub ahead of print].

16. FDA. FDA: cancer warnings required for TNF blockers. http://www.fda.gov/ NewsEvents/Newsroom/PressAnnouncements/ucm175803 htm 2009.

17. Ruperto N, Vesely R, Saint-Raymond A, Martini A. Impact of the European paediatric legislation in paediatric rheumatology: past, present and future. Ann Rheum Dis. 2013;72(12):1893-6.

18. Magnusson B, Board of Registry. The Swedish paediatric JIA-registry. Pediatric Rheumatol. 2014:12(S1):P5.

19. McErlane F, Foster HE, Davies R, Lunt M, Watson K, Symmons DPM, et al. Biologic treatment response among adults with juvenile idiopathic arthritis: results from the British Society for Rheumatology Biologics Register. Rheumatology. 2013;52:1905-13.

20. Mourao AF, Santos M, Melo-Gomes JA. Effectiveness and long-term retention of anti-tumour necrosis factor treatment in juvenile and adult patients with juvenile idiopathic arthritis: data from Reuma.pt. Rheumatology (Oxford). 2016;55(4):697-703.

21. Horneff G. Biologic-associated infections in pediatric rheumatology. Curr Rheumatol Rep. 2015;17:66

22. Horneff G, Schulz AC, Klotsche J, Hospach A, Minden K, Foeldvari I, et al. Experience with etanercept, tocilizumab and interleukin-1 inhibitors in systemic onset juvenile idiopathic arthritis patients from the BIKER registry. Arthritis Res Ther. 2017;19(1):256.

23. Becker I, Horneff G. Risk of serious infection in juvenile idiopathic arthritis patients associated with tumor necrosis factor inhibitors and disease activity in the German biologics in pediatric rheumatology registry. Arthritis Care Res (Hoboken). 2017;69(4):552-60.

24. Horneff G, Foeldvari I, Minden K, Moebius D, Hospach T. Report on malignancies in the German juvenile idiopathic arthritis registry. Rheumatology (Oxford). 2011;50(1):230-6.

25. Prince FH, Ferket IS, Kamphuis S, Armbrust W, ten CR, Hoppenreijs EP, et al. Development of a web-based register for the Dutch national study on biologicals in JIA: www.ABC-register.nl. Rheumatology (Oxford). 2008;47(9): 1413-6.

26. Prince FH, Twilt M, ten CR VRMA, Armbrust W, Hoppenreijs EP, et al. Longterm follow-up on effectiveness and safety of etanercept in juvenile idiopathic arthritis: the Dutch national register. Ann Rheum Dis. 2009;68(5): 635-41.

27. Otten $\mathrm{MH}$, Prince $\mathrm{FH}$, Armbrust $\mathrm{W}$, ten $\mathrm{CR}$ HEP, Twilt M, et al. Factors associated with treatment response to etanercept in juvenile idiopathic arthritis. JAMA. 2011:306(21):2340-7.

28. Beukelman T, Ringold S, Davis TE, DeWitt EM, Pelajo CF, Weiss PF, et al. Disease-modifying antirheumatic drug use in the treatment of juvenile idiopathic arthritis: a cross-sectional analysis of the CARRA registry. $J$ Rheumatol. 2012;39(9):1867-74.

29. Beukelman T, Haynes K, Curtis JR, Xie F, Chen L, Bemrich-Stolz CJ, et al. Rates of malignancy associated with juvenile idiopathic arthritis and its treatment. Arthritis Rheum. 2012;64(4):1263-71.

30. Beukelman T, Xie F, Chen L, Baddley JW, Delzell E, Grijalva CG, et al. Rates of hospitalized bacterial infection associated with juvenile idiopathic arthritis and its treatment. Arthritis Rheum. 2012;64(8):2773-80.

31. Beukelman T, Xie F, Baddley JW, Chen L, Delzell E, Grijalva CG, et al. Brief report: incidence of selected opportunistic infections among children with juvenile idiopathic arthritis. Arthritis Rheum. 2013;65(5):1384-9.

32. Winthrop KL, Novosad S, Baddley JW, Calabrese L, Chiller T, Polgreen P, et al. Opportunistic infections and biologic therapies in immune-mediated inflammatory diseases: consensus recommendations for infection reporting during clinical trials and postmarketing surveillance. Ann Rheum Dis. 2015; 74(12):2107-16.

33. Winthrop KL, Chen L, Fraunfelder FW, Ku JH, Varley CD, Suhler E, et al. Initiation of anti-TNF therapy and the risk of optic neuritis: from the Safety Assessment of Biologic ThERapy (SABER) study. Am J Ophthalmol. 2013; 155(1):183-9.

34. Abinun M. Risks of serious infections in children treated with biologic response-modifying drugs. Rheumatology. 2018;57(2):1-2.

35. Calzada-Hernández J, Anton J, Bou-Torrent R, Iglesias-Jiménez E, RicartCampos S, Martin de Carpi J, et al. Tuberculosis in pediatric patients treated with anti-TNFá drugs: a cohort study. Pediatric Rheumatology. 2015;13:54.

36. Ringold S, Weiss PF, Beukelman T, DeWitt EM, llowite NT, Kimura Y, et al. 2013 update of the 2011 American College of Rheumatology 
recommendations for the treatment of juvenile idiopathic arthritis: recommendations for the medical therapy of children with systemic juvenile idiopathic arthritis and tuberculosis screening among children receiving biologic medications. Arthritis Care Res (Hoboken). 2013;65(10): 1551-63.

37. Hsin YC, Zhuang L, Yeh K, Chang C, Horng J, Huang JL. Risk of tuberculosis in children with juvenile idiopathic arthritis: a nationwide population-based study in Taiwan. PLoS One. 2018;10(6). eCollection.

38. Ruperto N, Martini A. Networking in paediatrics: the example of the Paediatric Rheumatology International Trials Organisation (PRINTO). Arch Dis Child. 2011;96(6):596-601.

39. Swart J, Giancane G, Horneff G, Magnusson B, Hofer M, Alexeeva E, et al. Pharmacovigilance in juvenile idiopathic arthritis patients treated with biologic or synthetic drugs: combined data of more than 15,000 patients from Pharmachild and national registries. Arthritis Res Ther. 2018;20(1):285.

40. Groll A, Castagnola E, Cesaro S, Dalle J, Engelhard D, et al. Fourth European Conference on Infections in Leukaemia (ECIL-4): guidelines for diagnosis, prevention, and treatment of invasive fungal diseases in paediatric patients with cancer or allogeneic haemopoietic stem-cell transplantation. Lancet Oncol. 2014;15:327-40.

41. Mofenson LM, Brady M, Danner S, Dominguez K, Hazra R, Handelsman E, et al. Guidelines for the prevention and treatment of opportunistic infections among HIV-exposed and HIV-infected children: recommendations from CDC, the National Institutes of Health, the HIV Medicine Association of the Infectious Diseases Society of America, the Pediatric Infectious Diseases Society, and the American Academy of Pediatrics. MMWR Recomm Rep. 2009;58(RR-11):1-166.

42. Maertens J, Cesaro S, Maschmeyer G, Einsele H, Donnelly J, Alanio A, et al. ECIL guidelines for preventing Pneumocystis jirovecii pneumonia in patients with haematological malignancies and stem cell transplant recipients. J Antimicrob Chemother. 2016;71:2397-404.

43. Naidoo J, Mahomed N, Moodley H. A systemic review of tuberculosis with HIV coinfection in children. Pediatr Radiol. 2017:47:1269-76.

44. Tragiannidis A, Kyriakidis I, Zundorf I, Groll A. Invasive fungal infections in pediatric patients treated with tumor necrosis alpha (TNF-alpha) inhibitors. Mycoses. 2017;60:222-9.

45. Davies D, FAAP COID. Infectious complications with the use of biologic response modifiers in infants and children. Pediatrics. 2016;138:e11-21.

46. Hashkes PJ, Uziel Y, Laxer RM. The safety profile of biologic therapies for juvenile idiopathic arthritis. Nat Rev Rheumatol. 2010;6(10):561-71.

47. Lionetti G, Kimura Y, Schanberg L. Using registries to identify adverse events in rheumatic diseases. Pediatrics. 2013;132(5):1384-94.

48. ATS Board of Directors of the american Thoracic Society. Targeted tuberculin testing and treatment of latent tuberculosis infection. Am J Respir Crit Care Med. 2000;161(4 Pt 2):S221-47.

49. Nimmrich S, Horneff G. Incidence of herpes zoster infections in JIA patients. Rheumatol Int. 2015;35:465-70.

50. Nicolai R, Cortis E, Rava L, Bracaglia C, Pardeo M, Insalaco A, et al. Herpes virus infections during treatment with etanercept in juvenile idiopathic arthritis. J Pediatric Infect Dis Soc. 2016:5(1):76-9.

51. Leuvenink R, Aeschlimann F, Baer W, Berthet G, Cannizzaro E, Hofer M, et al. Clinical course and therapeutic approach to varicella zoster virus infection in children with rheumatic autoimmune diseases under immunosuppression. Pediatr Rheumatol Online J. 2016;14(1):34.

52. Curtis JR, Xie F, Yun H, Bernatsky WKL. Real-world comparative risks of herpes virus infections in tofacitinib and biologic-treated patients with rheumatoid arthritis. Ann Rheum Dis. 2016;75(10):1843-7.

53. Aeschlimann FA, Chong SL, Lyons TW, Beinvogl BC, Goez-Mogollon LM, Tan $\mathrm{S}$, et al. Risk of serious infections associated with biologic agents in juvenile idiopathic arthritis: a systematic review and meta-analyses. J Pediatr. 2019; 204:162-71.

\section{Publisher's Note}

Springer Nature remains neutral with regard to jurisdictional claims in published maps and institutional affiliations.

\section{Ready to submit your research? Choose BMC and benefit from:}

- fast, convenient online submission

- thorough peer review by experienced researchers in your field

- rapid publication on acceptance

- support for research data, including large and complex data types

- gold Open Access which fosters wider collaboration and increased citations

- maximum visibility for your research: over $100 \mathrm{M}$ website views per year

At BMC, research is always in progress.

Learn more biomedcentral.com/submissions 